\title{
HUBUNGAN KETAATAN KONSUMSI TABLET FE DENGAN KEJADIAN ANEMIA PADA IBU HAMIL DI WILAYAH KERJA PUSKESMAS KECAMATAN MAKASAR
}

\author{
Atikah Pustikasari $^{(1)}$, Melissa Apsari Jumantari ${ }^{(2)}$ \\ Program Studi D3 Keperawatan Universitas MH. Thamrin \\ atikahpustikasari73@gmail.com
}

\begin{abstract}
ABSTRAK
Masa kehamilan merupakan masa periode kritis dalam pertumbuhan dan perkembangan janin. Keadaan ini berkaitan dengan tingginya kejadian anemia pada masa kehamilan sehingga mempengaruhi kesehatan ibu dan janin. Anemia dapat meningkatkan resiko terjadinya kematian ibu pada saat persalinan. Anemia dipengaruhi oleh ketaatan ibu dalam mengkonsumsi tablet Fe selama kehamilan. Tujuan penelitian ini adalah untuk mengetahui hubungan ketaatan konsumsi tablet Fe dengan kejadian anemia pada ibu hamil di Wilayah Kerja Puskesmas Kecamatan Makasar. Metode Penelitian ini menggunakan metode deskriptif analitik dengan pendekatan cross sectional. Jumlah sampel 87 responden yang diambil dengan teknik simple random sampling. Hasil Penelitian ini menunjukkan sebanyak 45 responden $(51,7 \%)$ mengalami anemia dengan kadar $\mathrm{Hb}<11 \mathrm{~g} / \mathrm{dl}$. Hasil uji chi square menunjukkan ada hubungan bermakna antara ketaatan konsumsi tablet Fe, umur ibu, dan tingkat pendidikan dengan kejadian anemia. Sedangkan, variabel yang tidak ada hubungan yang bermakna antara pekerjaan ibu dengan kejadian anemia. Kesimpulannya Dengan konsumsi tablet Fe minimal 1 tablet sehari secara rutin selama kehamilan, dapat mencegah terjadinya anemia pada ibu hamil. Ibu hamil yang tidak taat dalam mengkonsumi tablet Fe berisiko 2.70 kali mengalami Anemia.
\end{abstract}

Kata Kunci : Anemia, Ketaatan Konsumsi Tablet Fe, Ibu Hamil

\section{PENDAHULUAN}

Anemia merupakan masalah kesehatan yang banyak ditemukan pada masyarakat terutama pada ibu hamil. Anemia pada WUS dapat menimbulkan kelelahan, badan lemah, penurunan kapasitas / kemampuan. Anemia pada umumnya terjadi diseluruh dunia terutama di negara berkembang (developing countries) dan pada kelompok sosio-ekonomi rendah. Secara menyeluruh anemia yang berada di negara berkembang sebesar $45 \%$ dan yang terdapat di negara maju sebesar 13\%. Di Amerika terdapat 12\% pada wanita usia subur (WUS) 15-49 tahun. $11 \%$ wanita usia subur mengalami anemia. Sementara presentase wanita hamil dan keluarga miskin terus meningkat dengan bertambahnya usia kehamilan $8 \%$ anemia di trimester I, $12 \%$ di trimester II, dan $29 \%$ di trimester III (Departemen Gizi dan Kesehatan Masyarakat, 2010).

Penyebab langsung kematian ibu mencapai 90\% terjadi pada saat persalinan dan setelah persalinan. Penyebab kematian ibu yang mengalami perdarahan (28\%), eklampsia (24\%), dan infeksi (11\%). Penyebab yang tidak langsung kematian ibu terdiri dari kurang energi kronis (KEK) pada kehamilan sebanyak 37\% dan anemia dalam kehamilan sebanyak 40\%. Kejadian anemia bagi ibu hamil dapat meningkatkan resiko terjadinya kematian pada ibu dibandingkan dengan ibu yang tidak terkena anemia (Depkes RI, 2012).

Prevalensi anemia yang terjadi pada ibu hamil di seluruh dunia adalah 51\%. Pada tahun 2005 terdapat $52 \%$ angka kejadian ibu hamil mengalami anemia di negara berkembang dan tahun 2008 angka kejadian pada ibu hamil di Asia Tenggara mencapai 48,2\%. Data anemia yang paling tinggi pada trimester ketiga kehamilan. Kejadian anemia terus meningkat secara bersamaan dengan usia kehamilan. (WHO, 2008). Survei yang dilakukan di Amerika Utara dan Eropa menunjukkan bahwa prevalensi anemia pada ibu hamil sekitar $10 \%$ 30\%. Di India terdapat $88 \%$ ibu hamil yang menderita anemia dan pada wilayah Asia lainnya mengalami anemia (Gibney et al, 2009). 
Di Indonesia, anemia salah satu masalah gizi yang utama yaitu kurang kalori protein, defisiensi vitamin A, dan gondok edemik. Anemia gizi merupakan kekurangan kadar hemoglobin dalam darah yang disebabkan karena defisiensi zat gizi diperlukan dalam pembentukan hemoglobin (Arisman, 2009). Kekurangan zat besi dapat menimbulkan gangguan pada pertumbuhan janin, sel tubuh, serta sel otak. Pada ibu hamil yang menderita berat dapat meningkatkan resiko morbiditas maupun mortalitas ibu dan bayi, kemungkinan dalam melahirkan bayinya mengalami BBLR dan premature lebih besar (Adriani dan Wirjatmadi, 2012). Kebutuhan zat besi ibu selama kehamilan berjumlah $900 \mathrm{mg}$ zat besi diantaranya $300 \mathrm{mg}$ untuk janin plasenta, $500 \mathrm{mg}$ untuk pertambahan eritrosit ibu, $100 \mathrm{mg}$ untuk darah janin. Suplementasi tablet zat besi salah satu cara yang bermanfaat dalam mengatasi anemia. Di Indonesia, suplementasi tablet zat besi sudah diberikan secara rutin pada ibu hamil dengan meminum tablet yang berjumlah $60 \mathrm{ml} /$ hari dapat menaikkan kadar hemoglobin 1 gr\% per bulan. Ibu hamil mendapat tablet zat besi yang berisi 90 tablet selama kehamilan.

Berdasarkan hasil penelitian Irwan Budiono (2009) menunjukkan bahwa faktor-faktor yang mempengaruhi terjadinya anemia pada ibu hamil adalah pendidikan ibu, penghasilan keluarga, tingkat konsumsi zat besi, tingkat konsumsi protein, tingkat konsumsi vitamin $\mathrm{C}$, kebiasaan minum teh, kebiasaan minum kopi dan kebiasaan konsumsi tablet besi (Fe). Disamping itu juga, kekurangan asam folat merupakan faktor konstribusi terhadap terjadinya anemia, terutama terjadinya pada ibu hamil. Kekurangan vitamin B 12 tidak umum terjadi, dan tidak mempunyai peranan penting dalam penyebab terjadinya anemia gizi (Rasmailah, 2004).

Dalam hasil penelitian Basuki (2002) menunjukkan bahwa kejadian anemia tertinggi pada trimester kedua $(86,3 \%)$. Faktor yang berpengaruh terhadap terjadinya anemia kehamilan trimester pertama antara lain interval kehamilan, usia kehamilan, dan lama pendidikan. Pada trimester kedua dan ketiga, faktor yang mempengaruhi terjadinya anemia kehamilan adalah konsumsi tablet fe dan kadar hemoglobin, sedangkan pada masa nifas yang berpengaruh terhadap terjadinya anemia adalah volume perdarahan pada persalinan, konsumsi tablet fe dan kadar hemoglobin sebelum persalinan (trimester ketiga) (www.libarary@unair.ac.id).

Beberapa faktor penyebab anemia pada ibu hamil antara lain tidak semua ibu hamil yang mendapat tablet zat besi meminumnnya secara rutin, hal ini disebabkan karena faktor ketidaktahuan pentingnya tablet zat besi untuk kehamillan. Dampak minum tablet zat besi dan penyerapan / respon tubuh terhadap tablet zat besi kurang baik sehingga tidak terjadi peningkatan kadar hemoglobin sesuai dengan yang diharapkan. Untuk pencegahan anemia pada ibu hamil diperlukan kepatuhan dalam mengkonsumsi tablet Fe. Ketaatan minum tablet Fe bagi ibu hamil sangat ditentukan oleh perhatian tenaga kesehatan dengan memberikan penyuluhan (promosi kesehatan), penjelasan bagi ibu hamil, dan tablet Fe yang tersedia. Maka dengan demikian tujuan penelitian ini adalah untuk mengetahui adakah hubungan antara ketaatan konsumsi tablet FE dengan kejadian anemia pada ibu hamil di wilayah puskesmas Kecamatan Makasar

\section{METODE}

Metode yang digunakan dalam penelitian ini yaitu deskriptif analitik dengan dilakukan pendekatan studi Cross Sectional merupakan suatu penelitian dimana pengambilan data terhadap beberapa variabel penelitian yang dilakukan pada satu waktu. Populasi pada penelitian ini yaitu seluruh jumlah ibu hamil di Wilayah Kerja Puskesmas Kecamatan Makasar Jakarta Timur Tahun 2016. Jumlah sampel pada penelitian ini adalah total 
populasi yang memenuhi kriteria inklusi berjumlah 87 responden. Teknik pengambilan sampel menggunakan metode simple random sampling (pengambilan sampel secara acak sederhana).

Alat pengumpulan data yang dipergunakan pada penelitian berupa kuesioner, observasi, dan wawancara. Prosedur pengambilan data dalam penelitian ini adalah tahap persiapan, tahap pemilihan responden, dan tahap penelitian. Teknik pengelolaan data antara lain Editing yaitu hasil wawancara yang dikumpulkan melalui kuesioner perlu disunting (edit) terlebih dahulu, Coding Sheet yaitu mengubah data dalam bentuk kalimat / huruf yang menjadi data angka, Data Entry yaitu jawaban dari masing-masing responden yang dalam bentuk angka / huruf dimasukkan ke dalam program (software) computer, Cleaning yaitu apabila semua data dari setiap sumber data (responden) selesai dimasukkan, maka perlu dilakukan pengecekan untuk melihat adanya kesalahan / kekurangan. Analisa univariat dilakukan hanya menghasilkan distribusi dan presentase dari tiap variabel yang diteliti seperti kejadian anemia, ketaatan konsumsi tablet Fe, umur ibu, tingkat pendidikan, dan pekerjaan. Analisa bivariat dilakukan untuk membuktikan adanya hubungan yang signifikan antara variabel independen (ketaatan konsumsi tablet Fe, umur ibu, tingkat pendidikan, dan pekerjaan) dengan variabel dependen (kejadian anemia).

\section{HASIL}

Pada Penelitian ini diperoleh hampir sebagian besar responden (51,7\%) mengalami anemia dengan kadar $\mathrm{Hb}<$ $11 \mathrm{~g} / \mathrm{dl}$. Sebagian besar responden $(51,7 \%)$ taat dalam mengkonsumsi tablet Fe ( $\geq 90$ tablet) selama kehamilan. Dilihat dari karakteristik responden, dari kategeori umur, sebanyak 54,0\% responden berada dalam kategori kelompok umur ibu yang beresiko ( $<20$ tahun dan $\geq 35$ tahun), 52,9\% responden berada dalam kategori kelompok tingkat pendidikan rendah $(\leq \mathrm{SMP})$. Sebagian besar responden $(55,2 \%)$ kategori kelompok tidak bekerja (ibu rumah tangga).

Hubungan ketaatan mengkonsumsi tablet Fe dan karakteristik responden terhadap kejadian anemia pada ibu hamil diperoleh hasil uji chi square diperoleh nilai $p$ value $=0,040$. Dengan nilai OR 2,70 Dapat disimpulkan ada hubungan yang bermakna antara ketaatan konsumsi tablet Fe dengan kejadian anemia pada ibu hamil. Ibu hamil yang tidak taat mengkonsumsi tablet Fe berpeluang 2,70 kali untuk mengalami kejadian anemia dari pada responden yang taat konsumsi tablet Fe.

Berdasarkan karakterstik responden hubungan antara umur dengan kejadian anemia pada ibu Hasil uji chi square diperoleh nilai $p$ value $=0,025$. Nilai OR 2.94 Dapat disimpulkan ada hubungan yang bermakna antara umur ibu dengan kejadian anemia pada ibu hamil, responden dengan kelompok umur yang resiko berpeluang 2,94 kali untuk mengalami kejadian anemia daripada umur ibu yang tidak beresiko. Hubungan tingkat Pendidikan dengan kejadian Anemia diperoleh nilai $p$ value $=0,043$. Nilai OR 2,66 maka disimpulkan bahwa ada hubungan yang bermakna antara tingkat pendidikan dengan kejadian anemia pada ibu hamil, responden dengan kelompok berpendidikan rendah berisiko 2,66 kali mengalami anemia dibandingkan oleh responden yang berpendidikan tinggi. Hubungan pekerjaaan responden dengan kejadian anemia hasil uji chi square diperoleh nilai $p$ value $=0,772$. Maka dapat disimpulkan tidak ada hubungan antara pekerjaan dengan kejadian Anemia pada ibu hamil. 


\section{PEMBAHASAN}

Dari hasil penelitian ini, diketahui bahwa sebagian besar ibu hamil $(51,7 \%)$ yang mengalami anemia (kad HB $<11 \mathrm{~g} / \mathrm{dl}$ ) ,hasil penelitian ini sejalan dengan penelitian yang dilakukan oleh Purbadewi et al (2013) menunjukkan bahwa sebagian besar responden mengalami anemia $(<11 \mathrm{gr} / \mathrm{dl})$ yang sebanyak 27 orang $(64,3 \%)$ namun berbeda dengan penelitian yang dilakukan oleh Mokodompit et al (2004) menunjukkan bahwa hanya 1/4 responden yang mengalami anameia, sebagian besar $(79,1 \%)$ responden tidak mengalami anemia. Anemia yang terjadi pada kehamilan disebabkan karena kurangnya asupan zat besi (Fe (Manuaba, 2004). Pada ibu hamil yang mengkonsumsi tablet Fe dianjurkan minimal 1 kali sehari. Atau 90 tablet selama kehamilan. Pada penelitian ini diperoleh bahwa ibu hamil yang tidak taat dalam mengkonsusmi Tablet Fe berisiko 2,7 kali mengalami anemia. Hasil penelitian ini pula sesuai dengan penelitian yang dilakukan oleh Astuti (2014) yang menunjukkan bahwa ibu yang tidak taat/patuh dalam mengkonsumsi tablet Fe, berisikp 2,586 mengalami anemia pada saat hamil.

Banyak faktor yang mempengaruhi ketaatan konsumsi tablet Fe tersebut ,salah satunya bu hamil masih kurang memahami tata cara dalam mengkonsumsi tablet Fe secara rutin dan bahaya anemia sehingga menyebabkan ibu tidak mau mengkonsumsi tablet Fe. Suplemen zat besi yang menyebabkan mual, muntah, nyeri ulu hati, dan diare. Namun, derajat mual yang ditimbulkan oleh setiap preparat tergantung pada jumlah zat besi yang diserapnya. Jumlah tablet Fe yang dikonsumsi minimal 90 tablet selama kehamilan dan frekuensi dalam mengkonsumsi tablet $\mathrm{Fe}$ diberikan secara rutin pada ibu hamil yang berjumlah $60 \mathrm{ml} / \mathrm{hari}$. Karena bisa menimbulkan efek samping yang kurang nyaman bagi ibu hamil ketika konsumsi tablet Fe. Sehingga terjadi ketidaktaatan dalam mengkonsumsi tablet Fe (Arifin, 2008).

Pada kondisi seperti inilah diperlukan dukungan keluarga dan informasi yang jelas disampaikan oleh petugas kesehatan untuk mempertahankan kesehatan dan mencegah terjadinya anemia pada ibu hamil. Salah satu upaya yang harus dilakukan adalah menganjurkan ibu hamil untuk mengkonsumsi tablet Fe dengan diberikan secara rutin pada ibu hamil minimal 1 kali sehari. Pada petugas kesehatan untuk turun langsung memberikan penyuluhan kesehatan terutama bagi ibu hamil mengenai pengawasan minum obat supaya ibu lebih taat dalam konsumsi tablet Fe serta ditempat pelayanan kesehatan tersedianya tablet Fe untuk mencegah terjadinya anemia. Hubungan karakteristik ibu hamil terhadap kejadian anemia pada penelitian ini ada hubungan yang bermakna antara umur ibu dimana umur ibu $<20$ tahun dan $>35$ tahun berisiko mengalami anemia, . Hasil penelitian ini sejalan dengan hasil penelitian yang dilakukan oleh Luthfiyati (2012) dan (Wijianto, 2012). Hal ini pun sesuai dengan apa yaang diungkapkan oleh Hidayati (2013) bahwa salah satu faktor yang menyeabkan aneia adalah faktor biomedis ibu yaitu umur, bila umur ibu relatif muda $\leq 20$ tahun akan berisio anemia dikarenakan pada umur tersebut masih dalam masa pertumbuhan yang masih membutuhkan zat gizi lebih banyakdibandingkan dengan umur diatasnya. Bila zat gizi yang dibutuhkan tidak terpenuhi maka akan terjadi kompetisi zat besi antara ibu denganbayinya (wijayanto,2012). Kadar $\mathrm{Hb}=7-10 \mathrm{~g} / \mathrm{d}$ l masih banyak ditemukan pada kelompok umur $\leq 20$ tahun sebanyak $46 \%$ dan kelompok 35tahun lebih banyak 45\% (Depkes, 2001). Usia ideal untuk ibu hamil adalah pada usia 20-35 tahun karena usia tersebut merupakan masa yang aman untukkehamilan dan kesiapan ibu yang bisa diharapkan untuk bisa menjaga kehamilannya. 
Pendidikan adalah proses perubahan prilaku menuju kedewasaan dan penyempurnaan hidup.pada penelitian ini responden dengan kelompok berpendidikan rendah berisiko 2,66 kali mengalami anemia dibandingkan oleh responden yang berpendidikan tinggi. Hasil penelitian ini tidak sejalan dengan penelitian yang dilakukan oleh Astuti (2014) yang menunjukkan bahwa kejadian anemia ibu hamil lebih banyak ditemukan pada responden dengan berpendidikan tinggi, namun biasanya seorang ibu khususnya ibu hamilyang berpendidikan tinggi dapat menyeimbangkan pola konsumsinya, apabila konsumsi sesuai maka asupan zat gizi yg diperoleh akan terpenuhi. Sehingga kemungkinan besar bisa terhindar dari malasah anemia. Tablet zat besi yang menimbulkan efek samping sehingga seseorang cenderung menolak mengkonsumsi tablet Fe.dalam penolakan tersebut sebenarnya karena ketidak tahuan mereka bahwa selama kehamilan sangat membutuhkan tambahan tablet Fe. Agar mengerti wanita hamil diberikan pendidikan yang tepat tentang manfaat tablet besi (Fe) ( Arisman, 2010). Kurangnya pengetahuan masyarakat mengenai pelayanan kesehatan akan mempengaruhi pemanfaatan fasilitas kesehatan yang ada sehingga berpengaruh pada kondisi kesehatan mereka ( Notoatmodjo, 2003).

Pada penelitian ini ibu hamil yang bekerja maupun yang tidak bekerja sama sama berisko mengalami anemia dan tidak ada hubung antara pekerjaan dengan kejadian anemia pada ibu hamil. Hasil penelitian ini tidak sejalan dengan penelitian yang dilakukan oleh Listianingsih (2012) menunjukkan bahwa sebagian besar responden ibu hamil yang tidak bekerja mengalami anemia dan ada hubungan yang bermakna antara pekerjaan dengan angka kejadian anemia pada ibu hamil. Pekerjaan biasanya berkaitan dengan pendidikan dan pendapatan seseorang. Ibu hamil yang tidak bekerja cenderung untuk mengalami anemia dibandingkan dengan ibu yang bekerja. Kemungkinan disebabkan karena ibu yang bekerja biasanya mempunyai pendidikan yang tinggi dan pendapatan yang lebih sehingga dapat mempunyai akses untuk membeli makanan yang mengandung zat besi. (Khumaidi,2005). Berat ringannya pekerjaan ibu juga akan mempengaruhi kondisi tubuh ibu dan pada akhirnya akan mempengaruhi status kondisinya. Ibu yang bekerja cenderung kurang istirahat, konsumsi makanan yang tidak seimbang dapat bersiko lebih besar mengalami anemia dibandingkan ibu yang tidak bekerja (Wijianto, 2002).

\section{KESIMPULAN DAN SARAN}

Pada Penelitian ini diperoleh hampir sebagian besar responden $(51,7 \%)$ mengalami . Dilihat dari karakteristik responden, dari kategeori umur, sebanyak 54,0\% responden berada dalam kategori kelompok umur ibu yang beresiko ( $<20$ tahun dan $\geq 35$ tahun), 52,9\% responden berada dalam kategori kelompok tingkat pendidikan rendah ( $\leq$ SMP). Sebagian besar responden $(55,2 \%)$ kategori kelompok tidak bekerja (ibu rumah tangga). Hubungan ketaatan mengkonsumsi tablet Fe dan karakteristik responden terhadap kejadian anemia pada ibu hamil diperoleh hasil ada hubungan yang bermakna antara ketaatan konsumsi tablet Fe dengan kejadian anemia pada ibu hamil. Ibu hamil yang tidak taat mengkonsumsi tablet Fe berpeluang 2,70 kali untuk mengalami kejadian anemia dari pada responden yang taat konsumsi tablet Fe. Berdasarkan karakterstik responden hubungan antara umur dengan kejadian anemia pada ibu Dapat disimpulkan ada hubungan yang bermakna antara umur ibu dengan kejadian anemia pada ibu hamil, responden dengan kelompok umur yang resiko berpeluang 2,94 kali untuk mengalami kejadian anemia daripada umur ibu yang tidak beresiko. Tingkat Pendidikan dengan kejadian Anemia disimpulkan bahwa ada hubungan yang bermakna antara tingkat 
pendidikan dengan kejadian anemia pada ibu hamil, responden dengan kelompok berpendidikan rendah berisiko 2,66 kali mengalami anemia dibandingkan oleh responden yang berpendidikan tinggi. Tidak ada Hubungan pekerjaaan responden dengan kejadian anemia . Kepada Fasilitas Kesehatan terutama Puskesmas Kecamatan Makasar, untuk dapat Diupayakan pada tenaga kesehatan untuk memberikan penyuluhan kesehatan minimal 3 kali saat melakukan pemeriksaan kehamilan yang diadakan di Puskesmas. Dapat meningkatkan kembali kualitas pelayanan yang diberikan pada ibu hamil dan menghimbau kepada ibu hamil untuk memanfaatkan pelayanan kesehatan yang ada di Puskesmas. Petugas kesehatan juga harus mengikutsertakan keluarga dalam pengawasan obat supaya ibu lebih taat dalam konsumsi tablet Fe serta perlunya asupan nutrisi pada ibu hamil dapat memenuhi kebutuhan zat gizi untuk mencegah terjadinya anemia. Untuk Peneliti Selanjutnya Pada penelitian ini dapat mengembangkan kembali dengan melanjutkan variabel lain yang belum diteliti, misalnya untuk mengetahui perubahan fisiologis ibu yang mempengaruhi anemia seperti paritas dan jarak kelahiran.

\section{UCAPAN TERIMA KASIH}

1. Terima kasih peneliti ucapkan kepada kepala dan staf Puskesmas Kecamatan Makasar yang telah memberikan ijin kepada peneliti dalam melakukan pengambilan data pada penelitian ini.

2. Terima kasih kepada berbagai pihak yang telah memberikan dukungan, waktu dan motivasi sehingga penelitian ini dapat diselesaian.

\section{DAFTAR PUSTAKA}

1. Departemen Gizi dan Kesehatan Masyarakat. (2010). Gizi dan Kesehatan Masyarakat (p. 215-224). Jakarta: Rajawali Pers. (2010)

2. Departemen Kesehatan RI, Profil Kesehatan Provinsi DKI Jakarta. (2012), Diperoleh pada tanggal 13 Mei 2016, dari http://www.depkes.go.id/download/PROFIL_KES_PROVINSI_2012/11\%20Profil_Kes.Prov.DKIJakart a_2012.pdf

3. WHO,. Worldwide Prevalence of Anemia 1993-2005 WHO Global Database On Anemia. Spain. WHO Press (2008)

4. Gibney, M., at.al . (2009). Gizi Kesehatan Masyarakat. Jakarta: EGC. (2009).

5. Arisman, M.B. Buku Ajar Ilmu Gizi; Gizi Dalam Daur Kehidupan (p. 144). Edisi 1. Jakarta: EGC. (2010).

6. Adriani \& Wirjatmadi, M. Pengantar Gizi Masyarakat. Edisi 1. Jakarta: Kencana Predana Media Group. (2012).

7. Irwan, Budiono. Prevalensi dan Determinan Kejadian Anemia Pada Ibu Hamil di Perkampungan Nelayan di Kelurahan Mangkang Wetan Semarang.- Volume 4 / No. 2 / Januari - Juni. KEMAS (2009).

8. Rasmailah. Anemia Kurang Besi dalam Hubungannya Dengan Infeksi Cacing Pada Ibu Hamil. (2004).. Diperoleh tanggal 14 April 2016, dari http://library.usu.ac.id/download/fkm/fkm-rasmailah8.pdf 
9. Mokodompit, L.N., Kapantow, N.H., Kawengian, S.E., \& Malonda, N.S. (2014). Hubungan Asupan Energi, Frekuensi Antenatal Care dan Ketaatan Konsumsi Tablet Fe Dengan Kejadian Anemia Pada Ibu Hamil di Puskesmas Wenang Kota Manado. Diperoleh pada tanggal 25 Maret 2016, dari dari http://fkm.unsrat.ac.id/wp-content/uploads/2015/02/LISA-MOKODOMPIT-JURNAL-1.pdf

10. Astuti, Dewi. Faktor Yang Berhubungan Dengan Kejadian Anemia Pada Ibu Hamil di Puskesmas Undaan Lor Kabupaten Kudus. (2014). Diperoleh pada tanggal 25 Maret 2016, dari https://publikasiilmiah.ums.ac.id/handle/11617/6723

11. Luthfiyati, Yana. Faktor-Faktor Yang Berhubungan Dengan Kejadian Anemia Pada Ibu Hamil di Puskesmas Jetis Kota Yogyakarta. (2012). Diperoleh pada tanggal 07 September 2016, dari http://journal.respati.ac.id/291-475-1-SM.pdf.

12. Hidayati, L.N. Faktor-Faktor Yang Berhubungan Dengan Kejadian Anema Pada Ibu Hamil di Puskesmas Kecamatan Palmerah Kota Administrasi Jakarta Barat. Depok: Fakultas Kesehatan Masyarakat Universitas Indonesia. (2013).

13. Arisman, M.B. . Buku Ajar Ilmu Gizi; Gizi Dalam Daur Kehidupan (p. 144). Edisi 1. Jakarta: EGC. 2010)

14. Notoatmodjo, S. Metodologi Penelitian Kesehatan (p.174-177). Jakarta: Rineka Cipta. (2010).

15. Listianingsih, Nia.. Hubungan Perilaku Ibu Hamil Dalam Mengkonsumsi Tablet Zat Besi (Fe) Terhadap Angka Kejadian Anemia di Puskesmas Kecamatan Pasar Rebo. Diperoleh tanggal 27 Mei 2016. Jakarta: Universitas MH Thamrin. (2014) 